\title{
Effect of Frozen Storage on Biochemical Changes and Fatty Acid Composition of Mackerel (Scomber japonicus) Muscle
}

\author{
Agustinelli Silvina Paola ${ }^{1,2} \&$ Yeannes Maria Isabel ${ }^{1,2}$ \\ ${ }^{1}$ Consejo Nacional de Investigaciones Científicas y Técnicas (CONICET), Argentina \\ ${ }^{2}$ Universidad Nacional de Mar del Plata (UNMDP), Facultad de Ingeniería, Grupo de Investigación en \\ Preservación y Calidad de Alimentos, Mar del Plata, Argentina \\ Correspondence: Agustinelli Silvina Paola, UNMDP, Juan B. Justo 4302. 7600, Mar del Plata, Argentina. \\ E-mail:silagustinelli@fi.mdp.edu.ar
}

Received: October 17, 2014 Accepted: November 28, 2014 Online Published: December 16, 2014

doi:10.5539/jfr.v4n1p135 URL: http://dx.doi.org/10.5539/jfr.v4n1p135

\begin{abstract}
The aim of the present work was to analyze the effect of frozen storage on biochemical characteristics in mackerel (Scomber japonicus). Fresh mackerel captured from Southwest Atlantic Ocean was frozen and then stored at $-19 \pm 1{ }^{\circ} \mathrm{C}$ for one year. Biochemical analyses were done at established sampling times: total volatile basic nitrogen (TVB-N), fatty acid profile, thiobarbituric acid values (TBA-RS) and colour determinations. After twelve months TVB-N increase correlated $\left(\mathrm{R}^{2}: 0.888\right)$ with storage time indicating the effect of enzymatic activity. Lipid content presented high degree of unsaturation, EPA (eicosapentaenoic acid; C20:5 $\omega$-3) and DHA (docosahexaenoic acid; C22:6 $\omega-3$ ) acids prevail among total $\omega-3$ acids. During frozen storage, polyunsaturated fatty acids, $\omega-3$ and Polyene Index (EPA + DHA / C16) contents decreased. Frozen storage of whole mackerel caused important changes in fatty acid composition simultaneously with an increase in lipid oxidation in fillets, measured as TBA-RS. Dark muscle was more sensitive to lipid oxidation than the light muscle. Color analysis showed that $L^{*}$ value was the parameter which presented more changes during frozen storage indicating loss of lightness in the dorsal and ventral fish fillet areas. The increase in $b^{*}$ value on the ventral zone indicated the presence of yellow pigments as result of lipid oxidation. Although the frozen storage technique represents important changes in mackerel samples, the high values of PUFA in muscle are still high over other fish species making mackerel an important nutritional resource.
\end{abstract}

Keywords: Scomber japonicus, frozen storage, dark muscle, light muscle, oxidative rancidity, volatile bases nitrogen, colour, fatty acid profile

\section{Introduction}

One abundant pelagic fatty fish specie in warm and temperate transition waters of the Atlantic, Indian, and Pacific oceans and adjacent seas is Chub mackerel (Scomber japonicus), which belong to the Scombridae family. It is recognized as a healthy food because of being a good source of high quality nutrients, particularly $\omega 3$ fatty acids (Oduro, Choi, \& Ryu, 2011). As other fatty fish species the mackerel presents a great seasonal variability in its lipid content that is controlled by the reproductive cycle (Huss, 1995). Because of this seasonal variability, the mackerel fisheries have to do stocks of raw material with similar characteristics in order to produce the same product throughout the year. In Argentina, the mackerel fishing season is between October to January.

Although freezing is an effective method of preserving foods, the presence of highly unsaturated lipids and the strong pro-oxidative systems naturally present in fish tissue makes mackerel products very susceptible to loss of quality by development of lipid oxidation (Hultin, 1992). The biochemical process involved in these deteriorative changes is related to several causes such as, the storage conditions, the fish muscle composition and the freshness before the freezing step (Aubourg, 1999; Losada, Barros-Velázquez, \& Aubourg, 2007; Nazemroaya, Sahari, \& Rezaei, 2011).

With respect to the fish biochemical changes, not all the fish sections and tissues present the same behaviour, since some are more susceptible to lipid oxidation than others when treated under equal conditions. This fact is partly explained by the differences found throughout a fish sample: the lipid content, the kinds of lipids and the different types of pro and antioxidant systems (Mai \& Kinsella, 1979; Decker \& Hultin, 1990; Petillo, Hultin, 
Krzynowek, \& Autio, 1998; Undeland, Ekstrand, \& Lingnert, 1998). From comparisons of dark muscle and light muscle, several studies have shown the dark muscle to be very prone to lipid oxidative changes. Petillo et al. (1998) obtained a faster decreased in the antioxidants systems of mackerel (Scomber scombrus) dark muscle in their study of storage on ice. Furthermore, it was determined by several authors that dark muscle contains large amounts of recognized pro-oxidants hemeproteins, low-molecular-weight (LMW) metals, and microsomal enzymes (Ke, Ackman, Linke, \& Nash, 1977; Hultin, 1992; Undeland et al., 1998; Sohn et al., 2005).

In this sense, as a pelagic fish the mackerel has a high content of dark muscle (Hultin 1992; Sohn et al., 2005). Lipid oxidation typically results in the formation of hydroperoxides as the primary oxidation product, which are readily decomposed to produce a variety of volatile compounds, including aldehydes, ketones, and alcohols, decreasing the sensory quality of fish and fish products (Huss, 1995; Shahidi \& Zhong, 2005). Oxidized lipids also interact with proteins inducing modification in the color due to the accumulation of yellow-brown pigments (Aubourg, 1998).

Taking into consideration the aforementioned information this study was carried out to determine specifically the fatty acid composition of mackerel (Scomber japonicus), considering the difference in dark and light muscles and to analyze biochemical changes in these muscles during frozen storage.

\section{Material and Methods}

\subsection{Sample Preparation}

The mackerel (Scomber japonicus) used in this study were caught in October in the Southwest Atlantic Ocean over the coast of Argentina. The same day landed, fish were washed and prepared to preserve frozen at $-19 \pm 1$ ${ }^{\circ} \mathrm{C}$. The average weight and length of the whole fish was $540 \pm 80 \mathrm{~g}$ and $30 \pm 1.6 \mathrm{~cm}$ (mean $\pm \mathrm{SD}, n=5$ ), respectively. A sample of four fillets, randomly selected, was separated to obtain the proximate composition of the whole, dark and light tissues. The remaining ones were stored at $-19 \pm 1{ }^{\circ} \mathrm{C}$ for $4,12,24,36$ and 48 weeks, respectively.

At each sampling time, four pieces were transferred to laboratory and thawed in a water bath under controlled conditions (at $12-15{ }^{\circ} \mathrm{C}$ for $2-3 \mathrm{~h}$ ) in order to process the samples and obtain two skinless fillets of each specimen.

The tissue was separated into dark and light muscle. The distribution $(\mathrm{w} / \mathrm{w})$ among the fractions was $84.6 \pm 3.1 \%$ and $15.4 \pm 1 . \%$, for light and dark muscle respectively.

\subsection{Proximate Composition}

Pooled samples ( $\mathrm{n}=4$ fillets) of the raw material was ground to analyzed the proximate composition. The dark and light muscles were also separated to obtain their individual composition. Moisture content was determined in triplicate by drying $5 \mathrm{~g}$ of minced fish at $105 \pm 1{ }^{\circ} \mathrm{C}$ until constant weight (Association of Official Analytical Chemists [AOAC], 1990) and ashes by heating the sample in a muffle furnace at $500 \pm 2{ }^{\circ} \mathrm{C}$ until the ash had a light appearance (AOAC, 1990). The N-total content was determined in duplicate according to the Kjeldahl method (AOAC, 1990) and protein content was calculated by multiplying the $\mathrm{N}$-total content by 6.25 .The total fat content was determined by acid-hydrolysis method (AOAC, 1990) in triplicate. All these results were expressed in wet basis and were presented as mean value \pm standard deviation (SD).

\subsection{Total Volatile Base-Nitrogen (TVB-N)}

TVB-N of the whole fillet was determined by direct distillation using the method by Giannini, Davidovich, \& Lupín (1979). $10 \mathrm{~g}$ of sample were placed into the distillation flask with $300 \mathrm{~mL}$ of distilled water and added $5 \mathrm{~g}$ magnesium oxide, and $2 \mathrm{~mL}$ of antifoam solution. The samples were boiled and distilled into $50 \mathrm{~mL}$ of boric acid solution with an indicator (methil red: bromocresol green, 1:3) in a $500 \mathrm{~mL}$ beaker. After distillation (230 $\mathrm{mL}$ ), the contents of the beaker were titrated with $0.1 \mathrm{~N}$ sulphuric acid. The quantity of TVB-N was expressed in $\mathrm{mg} / 100 \mathrm{~g}$ of fish flesh. Each determination was replicated twice.

\subsection{Analysis of Fatty Acid Pattern}

Lipids were obtained according to the method of Bligh and Dyer (1959) by chloroform/methanol/distilled water $(2: 2: 1.8, \mathrm{v} / \mathrm{v} / \mathrm{v})$. Two independent extracted lipids for each muscle and for the whole fish were stored under nitrogen in the dark at $-20^{\circ} \mathrm{C}$ for further analysis. The fatty acid pattern was measured in the lipids extracted from the dark and light muscle and from the whole fillet. After the fatty acids had been converted into methyl esters, they were analyzed by gas chromatography (Shimadzu ${ }^{\circledR} \mathrm{GC}-17 \mathrm{~A}$, Japan) equipped with a split injector, a Fused Silica Capillary Column Omegawax Supelco ${ }^{\circledR} 320(30 \mathrm{~m} / 0.32 \mathrm{~mm}, \mathrm{id} / 0.25 \mu \mathrm{m}$ film $)$ and a flame ionization detector (FID). The injection volume was $1 \mu \mathrm{l}$, done by duplicate. The chromatographic conditions 
were as follows: injection temperature: $260^{\circ} \mathrm{C}$; detector temperature: $250{ }^{\circ} \mathrm{C}$; initial oven temperature $190{ }^{\circ} \mathrm{C}$, programmed to increase gradually up to $225^{\circ} \mathrm{C}$. Nitrogen was used as the carrier gas at a linear flow of about 25 $\mathrm{cm} / \mathrm{s}$. The retention times and peak areas were processed using the Shimadzu ${ }^{\circledR}$ SMI Class - GC 10 software. Fatty acids were identified by comparison of their retention time and peak areas with those of a mix of reference standards (PUFA-1, Marine Source Supelco ${ }^{\circledR}$ Cat. No 4-7033) diluted in hexane (50 mg/l). Fatty acids were quantified as percentage ratio of peak areas with the total area.

\subsection{Thiobarbituric Acid Values (TBA-RS)}

TBA-RS concentrations of the dark and light muscles were determined by spectrophotometry using the method of the Botsoglou et al. (1994). TBA determinations were performed on TCA extracts from $2 \mathrm{~g}$ of minced muscle according to Tironi et al. (2007). Two independent extracts were obtained for each sample and subjected to the TBA reaction $\left(30 \mathrm{~min}, 70{ }^{\circ} \mathrm{C}\right)$ in duplicate. The absorbance readings were made at $532 \mathrm{~nm}$ for malonaldehyde (MDA).

TBA number was calculated as follows:

$$
\text { TBA number }(\mathrm{mg} M \mathrm{MDA} / \mathrm{kg} \text { muscle })=\frac{A b s \cdot M \cdot V_{a} \cdot V_{e} \cdot 1000}{\varepsilon \cdot l \cdot m}
$$

where MDA: malonaldehyde; Abs: absorbance at $532 \mathrm{~nm}$; M: molecular weight of MDA (72 g); $\mathrm{V}_{\mathrm{a}}$ : sample volume $(2 \mathrm{ml}) ; \mathrm{V}_{\mathrm{e}}$ : extract volume $(16 \mathrm{ml}) ; \varepsilon$ : molar extinction coefficient $\left(1.56 \times 10^{5} \mathrm{M} / \mathrm{cm}\right) ; 1$ : optical path $(1$ $\mathrm{cm})$; m: muscle weight.

\subsection{Colour Properties}

The colour measurement was performed on the internal surface of the fillet in the dorsal and ventral tissues areas. Colour determination was carried out using a LoviBond colorimeter RT500 (Neu-Isenburg, Germany) with an $8 \mathrm{~mm}$ diameter measuring area. The instrument was calibrated with a standard light plate. Tristimulus color coordinates were used to measure the degree of lightness $\left(L^{*}\right)$, redness $\left(+a^{*}\right)$ or greenness $\left(-a^{*}\right)$, and yellowness $\left(+b^{*}\right)$ or blueness $\left(-b^{*}\right)$. Colour changes $\left(\Delta \mathrm{E}^{*}\right)$ were calculated from the mean $\Delta \mathrm{L}^{*}, \Delta \mathrm{a}^{*}, \Delta \mathrm{b}^{*}$ values from each sample with the formula:

$$
\boldsymbol{\Delta} \boldsymbol{E}=\left(\boldsymbol{\Delta} \boldsymbol{L}^{2}+\Delta \boldsymbol{a} *^{2}+\Delta \boldsymbol{b}^{2}\right)^{1 / 2}
$$

where $\Delta \mathrm{L}^{*}, \Delta \mathrm{a}^{*}$, and $\Delta \mathrm{b}^{*}$ are the difference of $\mathrm{L}^{*}, \mathrm{a}^{*}$ and $\mathrm{b}^{*}$ values initial $\left(\mathrm{T}_{0}\right)$ and at each sampling point during frozen storage.

Five different positions on the surface of each muscle were measured for each storage time.

\subsection{Statistical Analysis}

Data were presented as mean \pm standard deviation (SD) and were subjected to analysis of variance (ANOVA). Significant means were compared by LSD-test (for comparison of dark and light muscle) at $\alpha=0.05$ level $(\mathrm{n}=3)$. The statistical analysis was done with the open-source software R (R Development Core Team, 2005).

\section{Results and Discussion}

\subsection{Compositional Data}

The mean and standard deviation in the whole fillet and in both tissues are summarized in Table 1. Mackerel (Scomber japonicus) whole muscle composed of water as the major component $(61.89 \%)$ followed by protein (20.69\%), fat (15.85\%) and ash (1.56\%). 
Table 1. Proximate composition of mackerel whole fillet, light muscle and dark muscle (g/100 g)

\begin{tabular}{llll}
\hline & Whole fillet & Light muscle & Dark muscle \\
\hline Water content $(\mathrm{g} / 100 \mathrm{~g})$ & $61.89(0.54)^{\mathrm{b}}$ & $64.97(0.69)^{\mathrm{a}}$ & $62.13(0.86)^{\mathrm{b}}$ \\
Protein content $(\mathrm{g} / 100 \mathrm{~g} \mathrm{wb})^{*}$ & $20.69(0.70)$ & $22.03(0.85)$ & $21.94(0.64$ \\
Fat content $(\mathrm{g} / 100 \mathrm{~g} \mathrm{wb})$ & $15.86(0.91)^{\mathrm{a}}$ & $11.99(0.10)^{\mathrm{b}}$ & $15.37(0.94)^{\mathrm{a}}$ \\
Ash content $(\mathrm{g} / 100 \mathrm{~g} \mathrm{wb})$ & $1.57(0.05)^{\mathrm{a}}$ & $1.45(0.07)^{\mathrm{a}}$ & $1.22(0.05)^{\mathrm{b}}$ \\
\hline
\end{tabular}

Data were presented as mean \pm standard deviation $(n=4)$; different letters in the same row indicate that the values are significantly different $(\mathrm{p}<0.05)$.

*For protein content, between mean values $(n=4)$ the difference is not significant $(p>0.05)$.

The result was in accordance with Casales, Yeannes and Zugarramurdi (1991) who working with the same species from Sudoccidental Ocean, reported that the mackerel muscle contained $62.46 \%$ of moisture, $26.46 \%$ of protein, $11.83 \%$ of fat and $2.26 \%$ of ash. The proximate composition of chub mackerel (Scomber japonicus) muscle, from the Mediterranean Sea, was also reported by Mbarki, Ben Miloud, Selmi, Dhib \& Sadok (2009), which were $71.78 \%$, ash $2.26 \%$, total protein $21.38 \%$ and total fat $4.13 \%$. Generally, variations in the proximate composition of fish flesh are closely related to sexual variations as nutrition, living area, fish size, catching season as well as other environmental condition (Undeland et al., 1998; Sanchez Pascua, Casales, \& Yeannes, 2001). Proximate composition of mackerel varied between seasons and with anatomical location since a large variation was observed in muscle lipid content (Ke et al., 1977; Sanchez Pascua et al., 2001). The dark muscle had the highest relative content of fat $(p<0.05), 15.36 \%$. Like other fatty fish, mackerel stores lipid in fat cells distributed among body tissues, specially under the skin, ventral and caudal area.

As explained by Mai and Kinsella (1979) the dark and light muscles represent two separate motor systems which operate independently and utilize different substrates. Dark muscle is used for continuous swimming activities and is able to metabolize lipids directly as energy. The light muscle is dependent on glycogen as a source of energy for the anaerobic metabolism (Huss, 1995; Undeland et al., 1998). Bae, Yoon and Lim (2010) reported that in chub and blue mackerel, the contents of moisture, crude protein and ash in dark muscle were lower than light muscle. The present study showed similar results.

\subsection{Chemical Measurements of Frozen: TVB-N}

The initial TVB-N value for the whole mackerel was $15.48 \pm 0.36 \mathrm{mg} / 100 \mathrm{~g}$ flesh. This indicates the freshness of the samples and is in agreement with the initial measured amount of TVB-N for mackerel, anchovy and hake (Ciarlo et al., 1987; Gómez-Estaca, Giménez, Gómez-Guillén, \& Montero, 2010; Nazemroaya et al., 2011). Changes in the total volatile base nitrogen levels held at $-19 \pm 1{ }^{\circ} \mathrm{C}$ are depicted in Figure 1.

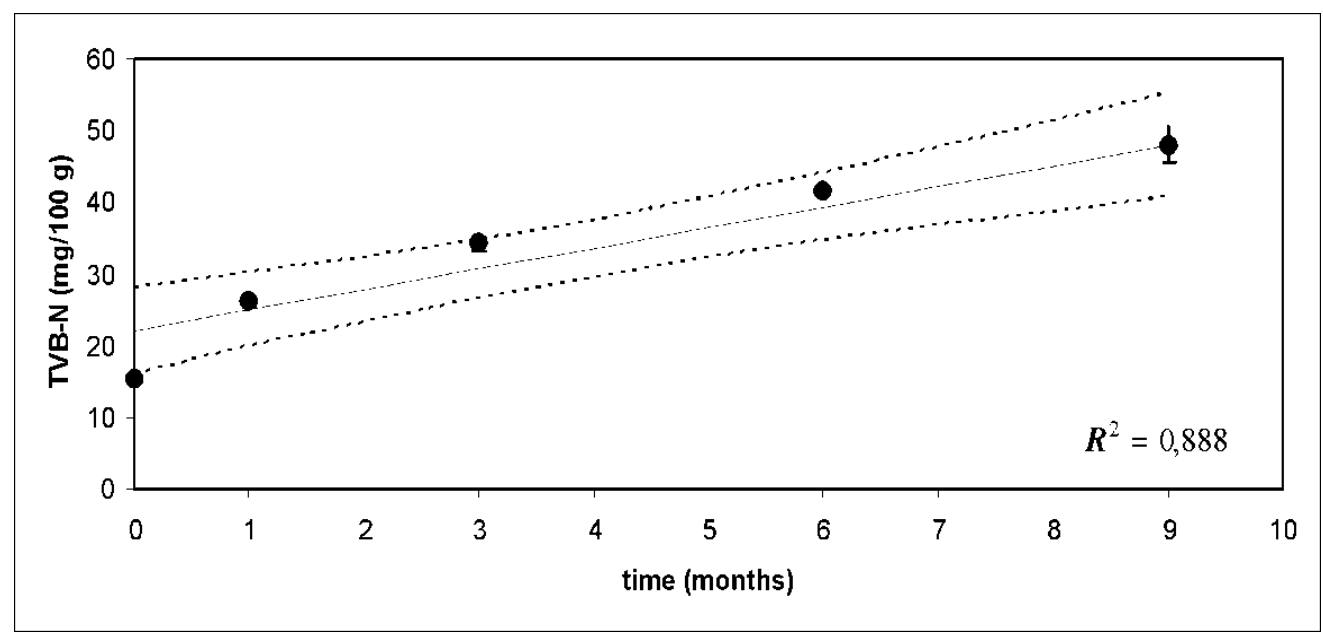

Figure 1. Changes in TVB-N values during frozen storage $\left(-19 \pm 1^{\circ} \mathrm{C}\right)$. Lines show the expected TVB-N values according to the linear regression (continuous line) and the $95 \%$ confidence intervals of the estimated (dotted lines) 
According to the obtained results, the values increased significantly $(\mathrm{p}<0,05)$ during the 9 months of study reaching $47.9 \mathrm{mg} 100 \mathrm{~g}-1$ flesh without evident spoilage. For several fish species, TVB-N values were reported to increase linearly with time during frozen storage as in the present study with acceptable sensorial characteristics (Ciarlo, Boeri, \& Giannini, 1985; Gómez-Estaca et al., 2010; Nazemroaya et al., 2011). Under frozen conditions the bacterial count and activity are gradually decreased, therefore the increase of TVB-N could be promoted by the Trimethylamine N-oxide (TMAO) breakdown (Huss, 1995). This breakdown can be catalyzed by endogenous enzyme present in muscle tissue resulting in equimolar quantities of DMA and FA which icrease the total volatile bases nitrogen (Hultin, 1992; Huss, 1995). Ciarlo et al. (1985) determined that there was an increment in TVB-N value of hake samples during frozen storage due to an increase in DMA. The rate of enzymatic cleavage of TMAO depends on the substrate, the temperature of storage, muscle integrity, and species (Ciarlo et al., 1985; Hultin, 1992).

A level of $35 \mathrm{mg} / 100 \mathrm{~g}$ has been considered the upper limit, above which fishery products are considered spoiled (Connell, 1990; EC Directive 95/149/EC). Nevertheless previous studies have shown how TVB-N quantities do not always indicate the beginning of the spoilage process, even when those values exceed the tolerance limit (Shakila et al., 2003). Köse and Erdem (2004) found that the TVB-N values do not follow a sensorial evaluation. Besides it is suggested that the TVB-N value depends on the species, catching season and region, age and sex of fish (Kilinc and Cakali, 2005) while the TVB-N value limit remains constant for all the teleost fishes.

As a zero order kinetic, the time coefficient of the equation represents the rate of volatile bases formation (mg TVB-N/100g w.b./month) during mackerel frozen storage. The evolution of TVB as a function of storage time was according to the following expression:

$$
\boldsymbol{T V} \boldsymbol{B}-\boldsymbol{N}=2.8681 \cdot \boldsymbol{t}+22.045
$$

A similar tendency was found by Nazemroaya et al. (2011) in samples of Spanish mackerel (Scomber commersoni), who obtained a total increment of $15 \mathrm{mg}$ TVB-N/100g after 6 months of storage at $-18^{\circ} \mathrm{C}$. While, in samples of a lean fish as the sea bass (Dicentrarchus labrax) the TVB-N total increment, after nine months of frozen storage at $-18{ }^{\circ} \mathrm{C}$, was $2.87 \mathrm{mg}$ TVB-N/100 g, obtained by Özyurt, Polat and Tokur (2007). Since the TVB-N increase during frozen storage is principally related to the breakdown of the trimethylamine oxide (TMAO) from enzymatic activity, the initial amount in flesh of this component is very important. The TMAO content varies with the season, size and age of fish, as well as environmental conditions to which the animal is subjected (Huss, 1995). Castell, Smith and Neal (2011) also detected that fish species stored without the dark lateral muscle presented a greatly reduced amount of the products developed by the TMAO breakdown.

\subsection{Fatty Acid Pattern}

A total of 34 fatty acids were identified by the gas chromatography technique. The fatty acids obtained as traces were joined in a same category as "others". The effect of frozen storage and the differences on the profile of the main fatty acids of the mackerel fillet and the edible parts are shown in Table 2, 3 and 4, respectively. 
Table 2. Profile of the main fatty acids detected in mackerel fillet

\begin{tabular}{|c|c|c|c|c|c|}
\hline \multirow{4}{*}{ Fatty acids (\%) } & \multirow{2}{*}{\multicolumn{5}{|c|}{ WHOLE FILLET }} \\
\hline & & & & & \\
\hline & \multicolumn{5}{|c|}{ FROZEN STORAGE TIME (Months) } \\
\hline & 1 & 3 & 6 & 9 & 12 \\
\hline \multicolumn{6}{|c|}{ Saturated fatty acids (SFA) composition } \\
\hline C $14: 0$ & $4.96(0.08)^{\mathrm{b}}$ & $5.27(0.24)^{\mathrm{b}}$ & $5.38(0.00)^{\mathrm{b}}$ & $5.76(0.37)^{\mathrm{b}}$ & $7.24(0.13)^{\mathrm{a}}$ \\
\hline C $16: 0$ & $13.54(0.34)^{\mathrm{c}}$ & $15.80(0.15)^{\mathrm{b}}$ & $17.25(0.00)^{\mathrm{b}}$ & $20.68(0.09)^{\mathrm{a}}$ & $21.77(0.71)^{\mathrm{a}}$ \\
\hline C $18: 0$ & $2.07(0.02)^{\mathrm{b}}$ & $2.02(0.06)^{b}$ & $3.54(0.00)^{\mathrm{a}}$ & $4.13(0.00)^{\mathrm{a}}$ & $5.02(0.49)^{\mathrm{a}}$ \\
\hline$\Sigma$ SFA $^{1}$ & $22.52(0.21)^{\mathrm{d}}$ & $25.07(0.47)^{\mathrm{cd}}$ & $28.16(0.06)^{\mathrm{bc}}$ & $33.05(1.30)^{\mathrm{ab}}$ & $36.62(1.43)^{\mathrm{a}}$ \\
\hline \multicolumn{6}{|c|}{ Monounsaturated fatty acid (MUFA) composition } \\
\hline C $18: 1 \omega 9$ & $12.41(0.31)^{\mathrm{c}}$ & $14.33(0.09)^{\mathrm{bc}}$ & $13.94(0.59)^{\mathrm{b}}$ & $14.46(0.11)^{\mathrm{b}}$ & $13.32(0.71)^{\mathrm{a}}$ \\
\hline C $20: 1 \omega 9$ & $9.65(0.21)^{\mathrm{ab}}$ & $10.11(0.18)^{\mathrm{a}}$ & $8.33(0.01)^{\mathrm{b}}$ & $5.57(0.04)^{\mathrm{c}}$ & $4.97(0.15)^{\mathrm{c}}$ \\
\hline C $22: 1 \omega 9$ & $3.82(0.00)^{\mathrm{a}}$ & $2.67(0.03)^{\mathrm{b}}$ & $1.82(0.00)^{\mathrm{c}}$ & $1.83(0.21)^{\mathrm{c}}$ & $1.62(0.19)^{\mathrm{c}}$ \\
\hline C $22: 1 \omega 11$ & $9.02(0.38)^{\mathrm{a}}$ & $7.13(0.20)^{\mathrm{b}}$ & $6.08(0.00)^{\mathrm{bc}}$ & $4.49(0.11)^{\mathrm{c}}$ & $4.00(0.06)^{\mathrm{c}}$ \\
\hline$\Sigma$ MUFA $^{1}$ & $40.93(0.50)^{\mathrm{b}}$ & $41.15(0.21)^{\mathrm{ab}}$ & $37.18(0.91)^{\mathrm{b}}$ & $34.60(0.30)^{\mathrm{ac}}$ & $33.07(1.17)^{\mathrm{c}}$ \\
\hline \multicolumn{6}{|c|}{ Polyunsaturated fatty acid (PUFA) composition } \\
\hline C $18: 2 \omega 6$ & $1.87(0.11)^{\mathrm{ab}}$ & $1.50(0.03)^{\mathrm{bc}}$ & $1.60(0.00)^{\mathrm{b}}$ & $1.55(0.01)^{\mathrm{b}}$ & $1.52(0.23)^{\mathrm{b}}$ \\
\hline $\mathrm{C} 18: 3 \omega 3$ & $1.05(0.03)^{\mathrm{a}}$ & $1.03(0.00)^{\mathrm{ab}}$ & $1.09(0.00)^{\mathrm{ab}}$ & $0.78(0.00)^{\mathrm{b}}$ & $1.08(0.05)^{\mathrm{b}}$ \\
\hline C $18: 4 \omega 3$ & $3.81(0.23)^{\mathrm{a}}$ & $3.86(0.02)^{\mathrm{a}}$ & $3.43(0.00)^{\mathrm{a}}$ & $2.37(0.00)^{\mathrm{b}}$ & $2.63(0.42)^{\mathrm{b}}$ \\
\hline C $20: 4 \omega 3$ & $1.79(0.02)^{\mathrm{a}}$ & $1.37(0.07)^{\mathrm{ab}}$ & $1.15(0.09)^{\mathrm{b}}$ & $1.11(0.21)^{\mathrm{ab}}$ & $1.01(0.01)^{\mathrm{b}}$ \\
\hline C $20: 5 \omega 3$ & $5.02(0.01)^{\mathrm{a}}$ & $4.66(0.01)^{\mathrm{ab}}$ & $4.42(0.00)^{\mathrm{ab}}$ & $4.08(0.18)^{\mathrm{ab}}$ & $4.00(0.47)^{\mathrm{b}}$ \\
\hline C $22: 6 \omega 3$ & $16.45(0.01)^{\mathrm{a}}$ & $14.98(0.68)^{\mathrm{b}}$ & $13.49(0.01)^{\mathrm{b}}$ & $13.49(0.00)^{\mathrm{b}}$ & $10.99(0.43)^{\mathrm{c}}$ \\
\hline$\Sigma$ PUFA $^{1}$ & $35.61(0.32)^{\mathrm{a}}$ & $33.57(1.14)^{\mathrm{ab}}$ & $30.78(0.12)^{\mathrm{bc}}$ & $28.52(0.19)^{\mathrm{cd}}$ & $25.01(2.48)^{\mathrm{d}}$ \\
\hline$\Sigma \omega 3$ & $28.12(0.32)^{\mathrm{a}}$ & $25.89(0.17)^{\mathrm{b}}$ & $23.57(0.01)^{\mathrm{bc}}$ & $21.83(0.37)^{\mathrm{c}}$ & $19.71(0.43)^{\mathrm{d}}$ \\
\hline$\Sigma \omega 6$ & $1.87(0.11)^{\mathrm{ab}}$ & $1.50(0.03)^{\mathrm{bc}}$ & $1.60(0.00)^{\mathrm{b}}$ & $1.55(0.01)^{\mathrm{b}}$ & $1.52(0.23)^{\mathrm{b}}$ \\
\hline$\Sigma \omega 6 / \Sigma \omega 3$ & $0.06(0.01)^{\mathrm{ab}}$ & $0.06(0.03)^{\mathrm{ab}}$ & $0.07(0.01)^{\mathrm{a}}$ & $0.07(0.00)^{\mathrm{a}}$ & $0.07(0.01)^{\mathrm{a}}$ \\
\hline$($ EPA + DHA $) / C 16$ & $1.59(0.04)^{\mathrm{a}}$ & $1.24(0.05)^{\mathrm{D}}$ & $1.04(0.00)^{\mathrm{D}}$ & $0.85(0.01)^{\mathrm{c}}$ & $0.69(0.02)^{\mathrm{c}}$ \\
\hline
\end{tabular}

${ }^{1}$ These values include other fatty acids that appear in a little proportion and are not present in the table. Different lower-case letters $(a, b, c, d, e, f)$ in the same row indicate significant differences within storage time $(p<0.05)$.

Table 3. Profile of the main fatty acids detected in mackerel light muscle

\begin{tabular}{|c|c|c|c|c|c|}
\hline \multirow{3}{*}{ Fatty acids (\%) } & \multicolumn{5}{|c|}{ LIGHT MUSCLE } \\
\hline & \multicolumn{5}{|c|}{ FROZEN STORAGE TIME (Months) } \\
\hline & 1 & 3 & 6 & 9 & 12 \\
\hline \multicolumn{6}{|c|}{ Saturated fatty acids (SFA) composition } \\
\hline C $14: 0$ & $4.18(0.08)^{\mathrm{c}}$ & $4.84(0.16)^{\mathrm{c}}$ & $4.84(0.00)^{\mathrm{c}}$ & $6.07(0.55)^{\mathrm{b}}$ & $9.97(0.01)^{\mathrm{a}}$ \\
\hline C $16: 0$ & $15.29(0.06)^{\mathrm{c}}$ & $16.30(0.55)^{\mathrm{c}}$ & $17.19(0.00)^{\mathrm{c}}$ & $20.08(0.86)^{\mathrm{b}}$ & $22.25(1.41)^{\mathrm{a}}$ \\
\hline C 18:0 & $2.94(0.13)^{\mathrm{a}}$ & $3.09(0.42)^{\mathrm{a}}$ & $3.23(0.01)^{\mathrm{a}}$ & $3.69(0.42)^{\mathrm{a}}$ & $3.94(0.71)^{\mathrm{a}}$ \\
\hline$\Sigma$ SFA $^{1}$ & $24.10(0.01)^{\mathrm{Ac}}$ & $26.04(1.17)^{\mathrm{ABC}}$ & ${ }^{c} 26.94(4.07)^{B}$ & $31.73(0.46)^{\mathrm{Ab}}$ & $38.05(0.65)^{\mathrm{Aa}}$ \\
\hline \multicolumn{6}{|c|}{ Monounsaturated fatty acid (MUFA) composition } \\
\hline C $18: 1 \omega 9$ & $11.61(0.03)^{\mathrm{ab}}$ & $12.55(0.37)^{\mathrm{ab}}$ & $14.06(0.00)^{\mathrm{b}}$ & $15.07(0.81)^{\mathrm{ab}}$ & $15.98(0.14)^{\mathrm{a}}$ \\
\hline C $20: 1 \omega 9$ & $9.57(1.14)^{\mathrm{a}}$ & $7.33(0.31)^{\mathrm{b}}$ & $6.32(0.00)^{\mathrm{bc}}$ & $4.89(0.46)^{\mathrm{c}}$ & $3.15(0.05)^{\mathrm{d}}$ \\
\hline C $22: 1 \omega 9$ & $3.93(0.48)^{\mathrm{a}}$ & $2.15(0.33)^{\mathrm{c}}$ & $2.75(0.01)^{\mathrm{b}}$ & $1.68(0.25)^{\mathrm{c}}$ & $1.40(0.09)^{\mathrm{c}}$ \\
\hline C $22: 1 \omega 11$ & $7.99(0.07)^{\mathrm{a}}$ & $6.30(0.24)^{\mathrm{c}}$ & $5.24(0.01)^{\mathrm{b}}$ & $4.10(0.67)^{\mathrm{c}}$ & $3.87(0.38)^{\mathrm{c}}$ \\
\hline$\Sigma$ MUFA $^{1}$ & $40.33(1.11)^{b}$ & $35.67(0.47)^{\mathrm{ab}}$ & $35.29(6.25)^{\mathrm{b}}$ & $33.00(0.24)^{\mathrm{ac}}$ & $32.13(0.10)^{\mathrm{c}}$ \\
\hline \multicolumn{6}{|c|}{ Polyunsaturated fatty acid (PUFA) composition } \\
\hline C $18: 2 \omega 6$ & $1.89(0.62)^{\mathrm{ab}}$ & $1.65(0.10)^{\mathrm{b}}$ & $1.38(0.01)^{\mathrm{c}}$ & $1.30(0.16)^{\mathrm{c}}$ & $1.25(0.22)^{\mathrm{c}}$ \\
\hline C $18: 3 \omega 3$ & $0.92(0.02)^{\mathrm{a}}$ & $1.13(0.07)^{\mathrm{ab}}$ & $0.92(0.00)^{\mathrm{ab}}$ & $1.03(0.00)^{\mathrm{b}}$ & $1.01(0.52)^{\mathrm{b}}$ \\
\hline C $18: 4 \omega 3$ & $3.48(0.76)^{\mathrm{ab}}$ & $3.68(0.20)^{\mathrm{a}}$ & $3.53(0.01)^{\mathrm{ab}}$ & $3.96(0.59)^{\mathrm{ab}}$ & $2.40(0.24)^{b}$ \\
\hline C $20: 4 \omega 3$ & $0.95(0.03)^{\mathrm{Ba}}$ & $1.62(0.41)^{\mathrm{a}}$ & $1.15(0.00)^{\mathrm{a}}$ & $1.05(0.02)^{\mathrm{a}}$ & $1.03(0.11)^{\mathrm{a}}$ \\
\hline C $20: 5 \omega 3$ & $3.85(0.27)^{\mathrm{b}}$ & $5.31(0.45)^{\mathrm{Aa}}$ & $5.21(0.00)^{\mathrm{Aa}}$ & $4.69(0.45)^{\mathrm{Aa}}$ & $3.93(0.47)^{\mathrm{b}}$ \\
\hline C $22: 6 \omega 3$ & $16.84(0.51)^{\mathrm{a}}$ & $16.74(0.18)^{\mathrm{a}}$ & $14.57(0.71)^{\mathrm{B}}$ & $13.48(0.18)^{\mathrm{b}}$ & $9.97(0.41)^{\mathrm{Bc}}$ \\
\hline$\Sigma$ PUFA $^{1}$ & $33.44(0.57)^{\mathrm{ab}}$ & $34.59(0.81)^{\mathrm{a}}$ & $31.75(0.87)^{\mathrm{b}}$ & $30.07(0.74)^{\mathrm{b}}$ & $23.09(0.92)^{\mathrm{c}}$ \\
\hline$\Sigma \omega 3$ & $26.04(0.12)^{\mathrm{ab}}$ & $28.48(0.98)^{\mathrm{a}}$ & $25.56(0.32)^{\mathrm{b}}$ & $24.21(0.26)^{\mathrm{b}}$ & $18.31(0.06)^{\mathrm{c}}$ \\
\hline$\Sigma \omega 6$ & $1.89(0.62)^{\mathrm{ab}}$ & $1.65(0.10)^{\mathrm{b}}$ & $1.38(0.01)^{\mathrm{c}}$ & $1.30(0.16)^{\mathrm{c}}$ & $1.25(0.22)^{\mathrm{c}}$ \\
\hline$\Sigma \omega 6 / \Sigma \omega 3$ & $0.07(0.02)^{\mathrm{a}}$ & $0.06(0.01)^{\mathrm{ab}}$ & $0.05(0.02)^{\mathrm{b}}$ & $0.05(0.00)^{\mathrm{b}}$ & $0.06(0.00)^{\mathrm{ab}}$ \\
\hline$($ EPA + DHA $) / C 16$ & $1.35(0.01)^{\mathrm{a}}$ & $1.35(0.08)^{\mathrm{a}}$ & $1.15(0.04)^{\mathrm{D}}$ & $0.90(0.01)^{\mathrm{c}}$ & $0.62\left(0.07^{\mathrm{a}}\right.$ \\
\hline
\end{tabular}

${ }^{1}$ These values include other fatty acids that appear in a little proportion and are not present in the table. 
Different lower-case letters ( $a, b, c, d, e, f)$ in the same row indicate significant differences within storage time (p $<0.05)$. Different capital letters $(A, B)$ in the same row for a given time indicate significant differences between muscles $(\mathrm{p}<0.05)$.

Table 4. Profile of the main fatty acids detected in mackerel light muscle

\begin{tabular}{|c|c|c|c|c|c|}
\hline \multirow{3}{*}{ Fatty acids $(\%)$} & \multicolumn{5}{|c|}{ DARK MUSCLE } \\
\hline & \multicolumn{5}{|c|}{ FROZEN STORAGE TIME (Months) } \\
\hline & 1 & 3 & 6 & 9 & 12 \\
\hline \multicolumn{6}{|c|}{ Saturated fatty acids (SFA) composition } \\
\hline C $14: 0$ & $5.02(0.41)^{\mathrm{bc}}$ & $5.04(0.34)^{\mathrm{bc}}$ & $4.95(0.35)^{\mathrm{c}}$ & $5.52(0.37)^{\mathrm{b}}$ & $8.21(0.49)^{\mathrm{a}}$ \\
\hline C $16: 0$ & $14.22(0.27)^{\mathrm{c}}$ & $17.01(1.50)^{\mathrm{b}}$ & $17.26(0.01)^{\mathrm{b}}$ & $19.15(0.10) b$ & $21.76(0.72)^{\mathrm{a}}$ \\
\hline C $18: 0$ & $3.30(0.08)^{\mathrm{a}}$ & $3.68(0.65)^{\mathrm{a}}$ & $4.08(0.00)^{\mathrm{a}}$ & $4.58(0.64)^{\mathrm{a}}$ & $4.40(0.25)^{\mathrm{a}}$ \\
\hline$\Sigma$ SFA $^{1}$ & $24.59(0.0)^{\mathrm{Ac}}$ & $27.86(2.46)^{\mathrm{Ab}}$ & $28.44(0.53)^{\mathrm{Abc}}$ & $31.71(1.44)^{\mathrm{Ab}}$ & $36.84(0.44)^{\mathrm{Aa}}$ \\
\hline \multicolumn{6}{|c|}{ Monounsaturated fatty acid (MUFA) composition } \\
\hline C $18: 1 \omega 9$ & $11.53(0.73)^{\mathrm{ab}}$ & $11.67(0.39)^{\mathrm{ab}}$ & $12.69(0.00)^{\mathrm{b}}$ & $16.11(0.03)^{\mathrm{ab}}$ & $16.23(0.51)^{\mathrm{a}}$ \\
\hline C $20: 1 \omega 9$ & $12.78(0.80)^{\mathrm{a}}$ & $8.46(0.66)^{\mathrm{b}}$ & $8.20(0.00)^{\mathrm{b}}$ & $5.53(0.05)^{\mathrm{c}}$ & $5.20(0.07)^{\mathrm{c}}$ \\
\hline C $22: 1 \omega 9$ & $3.53(0.20)^{\mathrm{a}}$ & $2.16(0.34)^{\mathrm{bc}}$ & $2.44(0.01)^{\mathrm{b}}$ & $1.70(0.08)^{\mathrm{c}}$ & $0.98(0.16)^{\mathrm{d}}$ \\
\hline C $22: 1 \omega 11$ & $7.01(0.14)^{\mathrm{a}}$ & $7.14(0.25)^{\mathrm{a}}$ & $6.32(0.00)^{\mathrm{a}}$ & $4.77(0.15)^{\mathrm{b}}$ & $3.43(0.34)^{\mathrm{c}}$ \\
\hline$\Sigma$ MUFA $^{1}$ & $38.96(0.51)^{\mathrm{b}}$ & $35.89(1.68)^{\mathrm{ab}}$ & $36.09(0.16)^{\mathrm{b}}$ & $33.72(0.13)^{\mathrm{ac}}$ & $32.55(0.73)^{\mathrm{c}}$ \\
\hline \multicolumn{6}{|c|}{ Polyunsaturated fatty acid (PUFA) composition } \\
\hline C $18: 2 \omega 6$ & $1.92(0.91)^{\mathrm{a}}$ & $1.56(0.21)^{\mathrm{b}}$ & $1.37(0.00)^{\mathrm{c}}$ & $1.35(0.14)^{\mathrm{c}}$ & $1.20(0.08)^{\mathrm{C}}$ \\
\hline C $18: 3 \omega 3$ & $0.97(0.23)^{\mathrm{a}}$ & $0.94(0.29)^{\mathrm{ab}}$ & $0.75(0.00)^{\mathrm{ab}}$ & $0.81(0.09)^{\mathrm{b}}$ & $1.10(0.06)^{b}$ \\
\hline C $18: 4 \omega 3$ & $1.86(0.03)^{\mathrm{a}}$ & $2.69(0.62)^{\mathrm{a}}$ & $2.37(0.00)^{\mathrm{a}}$ & $2.82(0.09)^{\mathrm{a}}$ & $2.24(0.18)^{\mathrm{a}}$ \\
\hline C $20: 4 \omega 3$ & $1.64(0.12)^{\mathrm{Aa}}$ & $1.65(0.48)^{\mathrm{a}}$ & $1.28(0.00)^{\mathrm{a}}$ & $0.97(0.13)^{\mathrm{a}}$ & $1.52(0.06)^{\mathrm{a}}$ \\
\hline C $20: 5 \omega 3$ & $3.97(0.29)^{\mathrm{a}}$ & $4.19(0.28)^{\mathrm{Ba}}$ & $3.83(0.00)^{\mathrm{Ba}}$ & $3.80(0.43)^{\mathrm{Ba}}$ & $2.89(0.74)^{\mathrm{a}}$ \\
\hline C $22: 6 \omega 3$ & $17.63(0.21)^{\mathrm{a}}$ & $17.28(0.61)^{\mathrm{a}}$ & $16.99(0.00)^{\mathrm{Aa}}$ & $13.41(0.62)^{\mathrm{b}}$ & $11.22(0.46)^{\mathrm{Ac}}$ \\
\hline$\Sigma$ PUFA $^{1}$ & $32.08(1.25)^{\mathrm{ab}}$ & $32.48(1.42)^{\mathrm{a}}$ & $31.01(0.24)^{\mathrm{ab}}$ & $27.79(0.51)^{\mathrm{bc}}$ & $24.51(1.48)^{\mathrm{c}}$ \\
\hline$\Sigma \omega 3$ & $26.07(0.61)^{\mathrm{a}}$ & $26.75(1.21)^{\mathrm{a}}$ & $25.58(0.14)^{\mathrm{ab}}$ & $21.81(0.87)^{\mathrm{bc}}$ & $18.97(1.87)^{\mathrm{c}}$ \\
\hline$\Sigma \omega 6$ & $1.92(0.91)^{\mathrm{a}}$ & $1.56(0.21)^{\mathrm{b}}$ & $1.37(0.00)^{\mathrm{c}}$ & $1.35(0.14)^{\mathrm{c}}$ & $1.20(0.08)^{\mathrm{c}}$ \\
\hline$\Sigma \omega 6 / \Sigma \omega 3$ & $0.07(0.03)^{\mathrm{a}}$ & $0.06(0.02)^{\mathrm{ab}}$ & $0.053(0.01)^{\mathrm{b}}$ & $0.06(0.00)^{\mathrm{ab}}$ & $0.06(0.03)^{\mathrm{ab}}$ \\
\hline$($ EPA + DHA $) / C 16$ & $1.52(0.01)^{\mathrm{a}}$ & $1.26(0.15)^{\mathrm{D}}$ & $1.21(0.00)^{\mathrm{D}}$ & $0.90(0.01)^{\mathrm{c}}$ & $0.65(0.08)^{\mathrm{a}}$ \\
\hline
\end{tabular}

${ }^{1}$ These values include other fatty acids that appear in a little proportion and are not present in the table.

Different lower-case letters ( $a, b, c, d, e, f)$ in the same row indicate significant differences within storage time ( $p$ $<0.05)$. Different capital letters $(A, B)$ in the same row for a given time indicate significant differences between muscles $(\mathrm{p}<0.05)$.

In general, the monoenes fraction was the highest in both dark and light tissues. The individual fatty acid analysis indicated that the main components in the inner layers and in the whole fillet were palmitic (C 16:0),

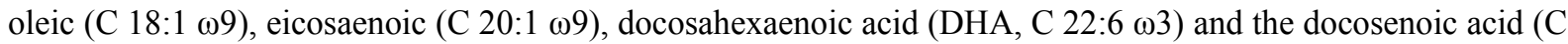
22:1 w11). These findings are in agreement with those reported by others authors in samples of chub mackerel (Scomber japonicus) and Atlantic mackerel (Scomber scombrus) (Maestre, Pazos, \& Medina, 2011). In the saturated fatty acid (SFA) fraction the C 16:0 was predominant, while in the monounsaturated (MUFA) fraction $\omega 9$ fatty acids contents were majority. Polyunsaturated fatty acid composition presented a higher DHA content than ecosapentaenoic acid (EPA, C20:5 w3), as it was found by Maestre et al. (2011) and Stolyhwo, Kolodziejska and Sikorski (2006) in samples of Atlantic mackerel (Scomber scombrus) and Nazemroaya et al. (2011) in Scomberomorus commersoni. Besides, both types of flesh had high concentrations of $\omega 3$ PUFAs including EPA and DHA as the major components of the PUFA fraction. EPA and DHA have been recognized as beneficial for human health since their biochemical effect in prevention and treatments of several disorder and diseases such as coronary heart disease, rheumatoid arthritis, cancers and others (Sahena et al., 2009). The contents of DHA and 13 fatty acids, among other components, found in this species were higher that those presented by Özogul, Özogul and Alagoz (2007) and Guler, Kiztanir, Aktumsek, Citil and Ozparlak (2008) on different fish species of sea and fresh water, indicating the importance of mackerel for nutrition and health human.

As shown in Table 2, the fatty acid composition showed changes during the frozen storage. The high content of unsaturated lipids as MUFA plus PUFA values in relation with SFA makes the mackerel muscle very susceptible 
to loss of quality by development of lipid oxidation (Nazemroaya et al., 2011). During the frozen storage the PUFA fraction present a significant decreased in both tissue sections, from 33.44 to 23.09 and 32.08 to 24.51 $\mathrm{g} / 100 \mathrm{~g}$ lipid, for light (Table 3) and dark muscle (Table 4) respectively. This lipid fraction acts as a substrate to initiate the lipid peroxidation, since their high degree of unsaturation allows removing a proton and producing a free radical. The presence of prooxidants compounds, such as heme compounds and free iron increase the lipid oxidation process giving as result the reduction in the PUFA lipid fraction (Hultin 1992; Undeland et al., 1998). Heme compounds accelerate the initiation of lipid oxidation (Wetterskog \& Undeland, 2004) and heme iron is the major catalyst of lipid oxidation (Hultin, 1992). The most affected were the $\omega-3$ fatty acids, especially the 22:6 $\omega 3$ (DHA). MUFA also decreased in all studied sections but less than the decrease obtained in the PUFA content. This behaviour can be attributed to the high susceptibility of PUFA to chemical and enzymatic oxidation compared to MUFA (Ke et al., 1977). In this study SFA showed an increase in all the sections studied during the frozen storage. These results are similar to those obtained by other authors for the whole mackerel during frozen storage, with an increase in SFA and a decrease in PUFA (Nazemroaya et al., 2011).

The polyene index (PI) (EPA+DHA/C16:0) has been suggested as a good indicator for determining lipid oxidation (Lubis \& Bukle, 1990). This index decreased (Table 2) in whole round mackerel as in both tissues studied. After 12 months of storage, the PI was reduced a 56.06\%, 53.84\% and 57.31\%, for the whole round mackerel and the light and dark tissue respectively. The negative relationship between this ratio and storage time showed that oxidation mechanisms are active during frozen storage (Ke et al., 1977).

\subsection{Lipid Oxidation}

The development of lipid oxidation in the whole fish and in both muscles of mackerel was studied-during a year in frozen storage and the results, in terms of TBA-RS changes, are presented in Figure 2.

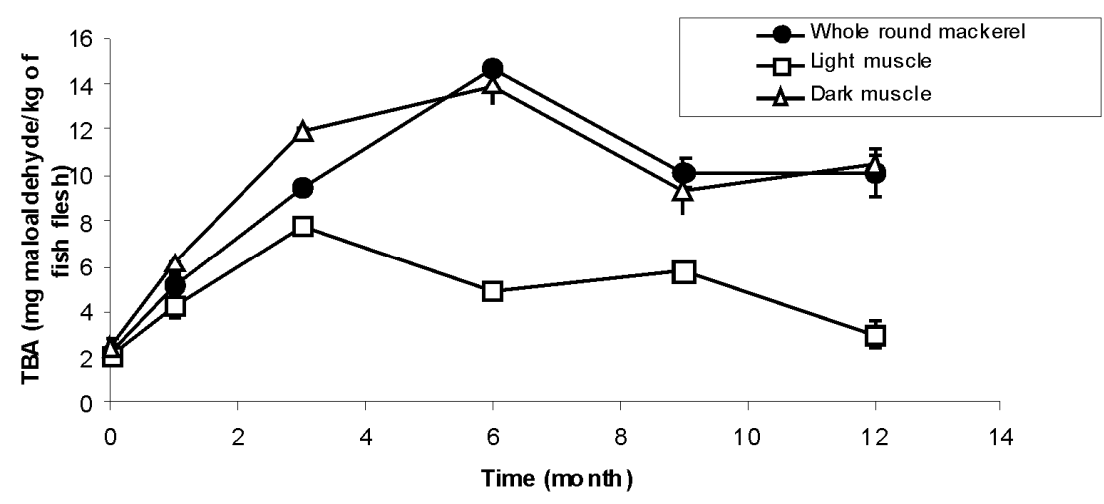

Figure 2. TBA-RS measured at $\lambda=532 \mathrm{~nm}$ in mackerel fillet and in light and dark mackerel tissues during frozen storage

There were not significant differences ( $p>0.05)$ between the initial values of TBA-RS obtained for both tissues. TBA-RS increased $(\mathrm{p}<0.05)$ in the whole round mackerel and in both tissues during the frozen storage. The values achieved for the dark muscle were close to the ones obtained for the whole mackerel, but higher than the TBA-RS values for light muscle during the entire studied period. The high lipid content of dark tissue, mostly unsaturated, makes it more susceptible to lipid oxidation than the ordinary muscle (Huss, 1995; Maestre et al., 2011). Undeland et al. (1998) concluded that the dark muscle presents the most unfavorable balance between pro-and anti-oxidants compounds resulting in a reduction of the lipid content stability. Same results were obtained by Petillo et al. (1998) in their studies on Atlantic mackerel (Scomber scombrus).

Figure 2 shows a clear tendency for the dark muscle to increase until the sixth month of storage, reaching an average maximum of $13.46 \pm 1.64 \mathrm{mg} \mathrm{MDA} \mathrm{kg}^{-1}$. After this sampling point, the values of TBA-RS decreased. On the other hand, the light tissue reached a TBA-RS value maximum of $7.72 \pm 0.1 \mathrm{mg} \mathrm{MDA} \mathrm{kg}^{-1}$ at the third month of storage followed by subsequent reduction. Sonh et al. (2005) obtained a similar behavoiur in the fish specie Seriola quinqueradiata, suggesting that the hydroperoxides break down to secondary products of oxidation (aldehydes, ketones, short chain fatty acids) was faster in the dark muscle than the light muscle.

The decrease in TBA-RS after six month of frozen storage can be attributed to decomposition of the secondary 
products of oxidation into tertiary products. Lipid oxidation is a complex process that involves formation of different types of compounds, being the most unstable and therefore susceptible to break down to short-chain compounds or to react with other molecules (Huss, 1995). Similar results have been found in frozen minced mackerel (Scomber scombrus) (Losada et al., 2007), in steaks of Micromesistius poutassou, a gadidae fish specie (Aubourg, 1999) and in salmon (Salmo salar) fillets (Tironi, Tomás, \& Añón, 2010).

Regarding the whole fillet, an increase was observed up to the sixth month, reaching a maximum of $14.65 \pm 0.25$ mg MDA kg-1 similar to that obtained for the dark muscle. Similar results were obtained by Stodolnik, Stawicka, Szczepanik and Aubourg (2005) in whole Atlantic mackerel (Scomber scombrus) during storage at $-20{ }^{\circ} \mathrm{C}$, reaching a maximum value $(\approx 20 \mathrm{mg} \mathrm{MDA} / \mathrm{kg})$ after 5 months of treatment. Although the whole fillet has more quantity of light muscle than the dark one, the oxidation process is mainly influenced by the changes in the dark muscle and skin, because these sections are rich in pro-oxidant components and high unsaturated lipid content (Ke et al., 1977; Undeland et al., 1998.). It is well known that lipid oxidation can be catalyzed by the hemeproteins and iron. Undeland et al. (1998) worked with herring (Clupea harengus) founding that iron content in dark muscle $(22.5 \mathrm{mg} / \mathrm{kg})$ was eight times higher than in light muscle $(3 \mathrm{mg} / \mathrm{kg})$, also a higher copper content was obtained. Regarding to Mackerel, Decker and Hultin (1990) found that dark muscle iron concentration in their free ion form was five times higher than in the light muscle. Ke et al. (1977) found that the skin lipids from mackerel were oxidized much faster than the meat fats.

The TBA-RS activity of the whole fillet similar to the dark muscle one indicates the high susceptibility of the specie and the importance of prevent the lipid oxidation during the samples processing.

\subsection{Color Modifications}

The results of $a^{*}, b^{*}$ and $L^{*}$ during frozen storage obtained for the dorsal and ventral zones are shown in fig 3 . For the ventral area the values of $a^{*}$ and $b^{*}$ were $2.015 \pm 0.121$ and $15.445 \pm 0.237$, respectively and for the dorsal area $1.715 \pm 0.190$ and $13.070 \pm 0.254$. No significant differences were detected in the $a^{*}$ and $b^{*}$ coordinates between the studied areas ( $\mathrm{p}>0.05$ ).
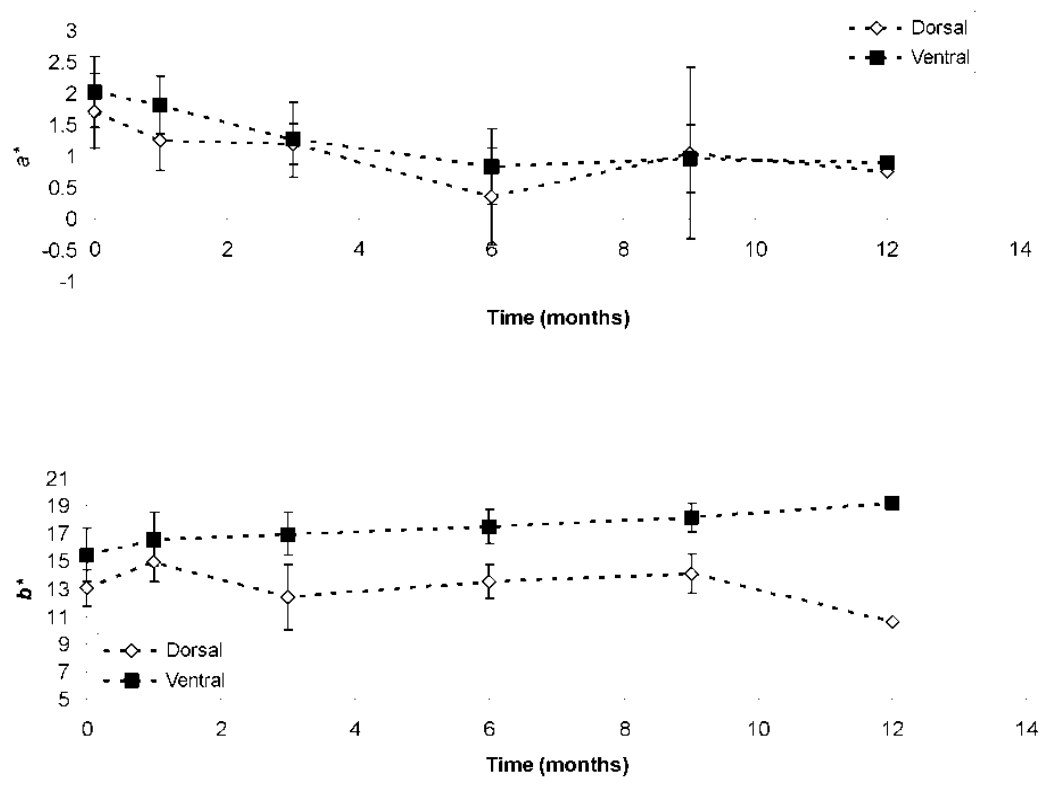


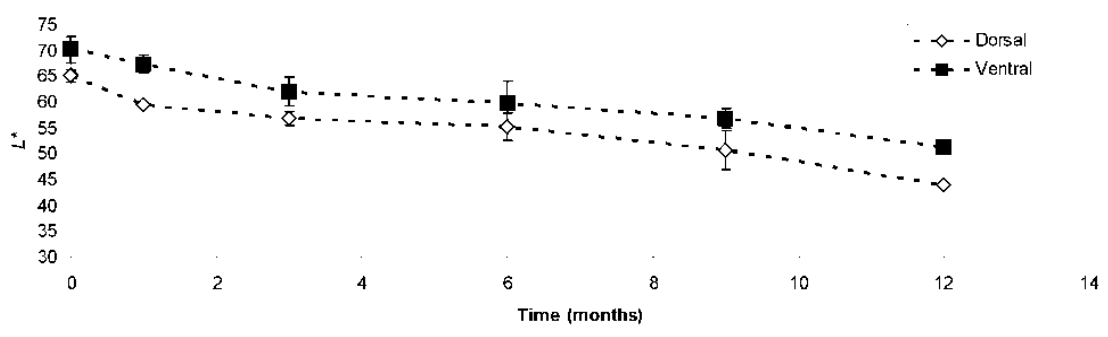

Figure 3. Colour changes during frozen storage of whole mackerel. Measures were done on the dorsal and ventral fillet zones

After a long period ( 30 weeks) of frozen storage the mackerel samples lost the fresh appearance and the color became grey. The $a^{*}$ parameter showed a slight but not significant increase in the dorsal area while the parameter $b^{*}$ showed a significant $(\mathrm{p}<0.05)$ increase in the ventral zone. The tendency of $b^{*}$ to the yellow color could be related to oxidative process that occurs during storage, which results in colored compounds as the called Schiff bases (Wetterskog \& Undeland, 2004). The Schiff bases are formed from the reaction between aldehydes generated during lipid oxidation and protein amino groups, which induces the loss of functional properties of the proteins (Chopin, Kone, \& Serot, 2007). This relationship between yellowing and non-enzymatic browning reactions was studied by Tongnuanchan, Benjakul, Prodpran and Songtipya (2011) in films made from tilapia (Oreochromis niloticus) muscle protein, correlating higher TBA-RS values with high values of the parameter $b^{*}$. The presence of higher fat content in the ventral zone, as any residual blood or viscera after evisceration, would influence color changes.

The initial values of the coordinate $L^{*}$ were $70.075 \pm 0.120$ and $64.975 \pm 0.643$ for the ventral and dorsal areas, respectively, with a significant difference $(\mathrm{p}<0.05)$ between them. Dorsal zone was darker and less luminous than the ventral one which is related with the natural fish camouflage.

The $L^{*}$. value decreased with storage time in both studied areas, with the ventral side being whiter than the dorsal for the whole time. These changes could be related to a dehydration process as a result of temperature fluctuations at each sampling point with the freezer opening (Connell, 1990). Same results were found by Hamre, Lie and Sandnes (2003) in their studies on herring (Clupea harengus L.).

The color changes expressed as $\Delta \mathrm{E}$ is presented in Figure 4.

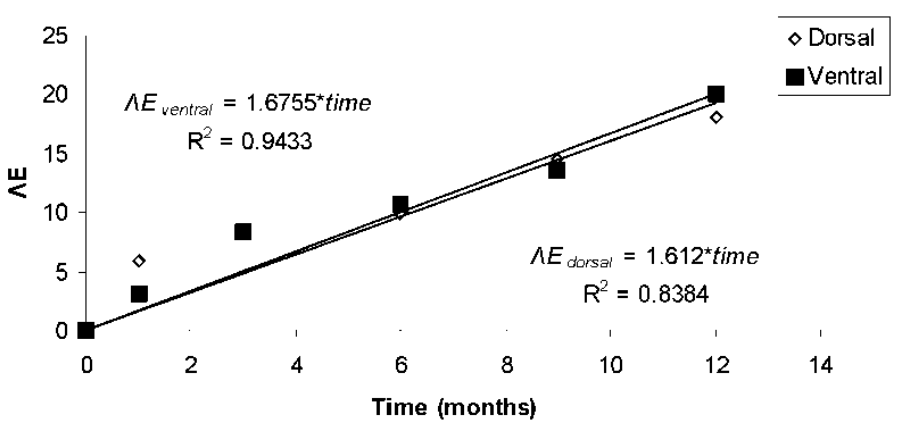

Figure 4. The mean colour changes $(\Delta \mathrm{E})$ of the ventral and dorsal areas of mackerel during frozen storage

The results presented in figure 4 indicate that in the ventral and dorsal there were changes in the color parameters during storage at $-19{ }^{\circ} \mathrm{C} \pm 1{ }^{\circ} \mathrm{C}$ without significant differences $(\mathrm{p}>0.05)$ between them. According to the previously analysis performed on each color coordinate, the changes obtained in the $L^{*}$ value presented the greatest contribution to the $\Delta \mathrm{E}$ results while the contribution $\mathrm{a}^{*}$ changes were negligible. Thereafter the main parameter modified during frozen storage was $L^{*}$. Since this parameter is related to dehydration, this would be the main reason for the changes obtained in color, having a slight contribution of the lipid oxidation process 
shown as the increase in $b^{*}$ value.

\section{Conclusions}

Frozen storage of whole mackerel caused important changes in fatty acid composition simultaneously with an increase in lipid oxidation in fillets, measured as TBA-RS. Polyunsaturated fatty acids, $\omega-3$ and Polyene Index $(\mathrm{EPA}+\mathrm{DHA} / \mathrm{C} 16)$ contents decreased with frozen storage. Dark muscle resulted more sensitive to lipid oxidation than the light muscle. However, the high values of PUFA in muscle are still high over other fish species, making mackerel an important nutritional resource. Color analysis showed that $L^{*}$ value was the parameter which presented more changes during frozen storage indicating loss of lightness in the dorsal and ventral fish fillet areas. The heterogeneous nature of the fillet due to the different tissues with their own proximal composition and behavior during frozen storage showed the complexity of the raw material and explain the evolution of physicochemical changes during the studied process.

\section{Acknowledgments}

This work was supported by grants from the Consejo Nacional de Investigaciones Científicas y Técnicas (CONICET-PIP 0403) and the Universidad Nacional de Mar del Plata (15/G324 and ING330/11). The authors wish to thank enterprise COPECA SA for the supply of raw material, and Lic. Silvana Guccione, from OMEGASUR SA, for her technical support in determining fatty acid profiles.

\section{References}

Antonacopoulos, N. (1971). Comparison of sensory and objective methods for quality evaluation of fresh and frozen Saltwater Fish. In R. Kreuser, Fish Inspection and Quality Control (pp. 180-182). Fishing News Books.

Association of Official Analytical Chemists [AOAC]. (1990). Official methods of analysis (15th ed.). Washington DC.

Aubourg, S. P. (1998). Detección de fluorescencia en sistemas modelo conteniendo aldehídos: relación con la alteración de pescado. Grasas y Aceites, 49(5-6), 419-424. http://dx.doi.org/10.3989/gya.1998.v49.i5-6.752

Aubourg, S. P. (1999). Lipid damage detection during the frozen storage of an underutilized fish species. Food Research International, 32(7), 497-502. http://dx.doi.org/10.1016/S0963-9969(99)00123-4

Bae, J. H., Yoon, S. H., \& Lim, S. Y. (2010). A comparison of the biochemical characteristics of different anatomical regions of chub (Scomber japonicus) and blue mackerel (Scomber australasicus) muscles. Korean Journal of Fisheries and Aquatic Science, 43, 6-11. http://dx.doi.org/10.5657/kfas.2010.43.1.006

Bligh, E. G., \& Dyer, W. J. (1959). A rapid method for total lipid extraction and purification. Canadian Journal of Biochemistry and Physiology, 37, 911-917. http://dx.doi.org/10.1139/o59-099.

Botsoglou, N. A., Fletouris, D. J., Papageorgiou, G. E., Vassilopoulos, V. N., Mantis, A. J., \& Trakatellis, A. G. (1994). Rapid, sensitive, and specific thiobarbituric acid method for measuring lipid peroxidation in animal tissue, food, and feedstuff samples. Journal of Agricultural and Food Chemistry, 42(9), 1931-1937. http://dx.doi.org/10.1021/jf00045a019

Casales, M. R., Yeannes, M. I., \& Zugarramurdi, A. (1991). Conservas de caballa: composición química proximal y evaluación sensorial. Alimentaria, 219, 93-98.

Castell, C. H., Smith, B., \& Neal, W. (2011). Production of dimethylamine in muscle of several species of gadoid fish during frozen storage, especially in relation to presence of dark muscle. Journal of the Fisheries Research Board of Canada, 28(1), 1-5. http://dx.doi.org/10.1139/f71-001

Chopin, C., Kone, M., \& Serot, T. (2007). Study of the interaction of fish myosin with the products of lipid

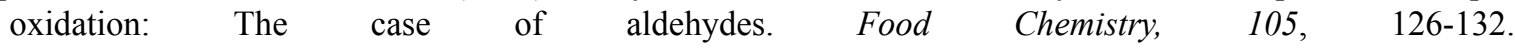
http://dx.doi.org/10.1016/j.foodchem.2007.03.058

Ciarlo, A. S., Boeri, R. L., \& Giannini, D. H. (1985). Storage life of frozen blocks of Patagonian hake (Merluccius hubbsi) filleted and minced. Journal of Food Science, 50, 722-726. http://dx.doi.org/10.1111/j.1365-2621.1985.tb13782.x

Ciarlo, A. S., Almadós, M. E., Boeri, R. L., Paredi, M. E., Yeannes, M. I., \& Giannini, D. H. (1987). Incremento en el contenido de bases volátiles totales (NBV) debido al proceso de congelación de merluza (Merluccius hubbsi). Revista de ciencias agrarias, 8(3-4), 29-33.

Connell, J. (1990). Control of Fish Quality (3rd ed.). London: Fishing News Books, Blackwell Scientific 
Publications.

Decker, E. A., \& Hultin, H. O. (1990). Factors influencing catalysis of lipid oxidation by the soluble fraction of mackerel muscle. Journal of Food Science, 55(4), $947-950$. http://dx.doi.org/10.1111/j.1365-2621.1990.tb01571.x

Giannini, D. H., Davidovich, L. A., \& Lupín, H. M. (1979). Adaptación de métodos de uso comercial para la determinación de nitrógeno básico volátil en merluza (Merluccius hubbsi). Revista de Agroquímica y tecnología de los alimentos, 19(1), 55-60.

Gómez-Estaca, J., Giménez, B., Gómez-Guillén, C., \& Montero, P. (2010). Influence of frozen storage on aptitude of sardine and dolphinfish for cold-smoking process. LWT - Food Science and Technology, 43(8), 1246-1252. http://dx.doi.org/10.1016/j.lwt.2010.04.001

Guler, G. O., Kiztanir, B., Aktumsek, A., Citil, O. B., \& Ozparlak, H. (2008). Determination of the seasonal changes on total fatty acid composition and $\omega 3 / \omega 6$ ratios of carp (Cyprinus carpio L.) muscle lipids in $\begin{array}{lllll}\text { Beysehir Lake } \quad \text { (Turkey). } & \text { Food }\end{array}$ http://dx.doi.org/10.1016/j.foodchem.2007.10.080

Hamre, K., Lie, Ã., \& Sandnes, K. (2003). Development of lipid oxidation and flesh colour in frozen stored fillets of Norwegian spring-spawning herring (Clupea harengus L.). Effects of treatment with ascorbic acid. Food Chemistry, 82(3), 447-453. http://dx.doi.org/10.1016/S0308-8146(03)00070-0

Hultin, H. O. (1992). Biochemical deterioration of fish muscle. Developments in food science., 30, 125-138.

Huss, H. H. (1995). Quality and quality changes in fresh fish. FAO Fisheries Technical Paper 348 (p. 203 ). Rome: FAO.

Ke, P. J., Ackman, R. G., Linke, B. A., \& Nash, D. M. (1977). Differential lipid oxidation in various parts of frozen mackerel. International Journal of Food Science \& Technology, 12(1), 37-47. http://dx.doi.org/10.1111/j.1365-2621.1977.tb00083.x

Kilinc, B., \& Cakali, S. (2005). Determination of the shelf life of sardine (Sardina pilchardus) marinades in tomato sauce stored at $4{ }^{\circ} \mathrm{C}$. Food Control, 16, 639-644. http://dx.doi.org/10.1016/j.foodcont.2004.07.004

Köse, S., \& Erdem, E. (2004). An investigation of quality changes in anchovy (Engraulis encrasicolus, L.1758) stored at different temperatures. Turkish Journal of Veterinary \& Animal Sciences, 28, 575-582.

Losada, V., Barros-Velázquez, J., \& Aubourg, S. P. (2007). Rancidity development in frozen pelagic fish: Influence of slurry ice as preliminary chilling treatment. LWT - Food Science and Technology, 40(6), 991-999. http://dx.doi.org/10.1016/j.lwt.2006.05.011

Lubis, Z., \& Buckle, K. A. (1990). Rancidity and lipid oxidation of dried-salted sardines. International Journal of Food Science \& Technology, 25(3), 295-303. http://dx.doi.org/10.1111/j.1365-2621.1990.tb01085.x

Maestre, R., Pazos, M., \& Medina, I. (2011). Role of the raw composition of pelagic fish muscle on the development of lipid oxidation and rancidity during storage. Journal of Agricultural and Food Chemistry, 59(11), 6284-6291. http://dx.doi.org/10.1021/jf200686z

Mai, J., \& Kinsella, J. E. (1979). Lipid composition of dark and light muscle from light sucker (Catostomus commersoni). Journal of Food Science, http://dx.doi.org/10.1111/j.1365-2621.1979.tb03456.x

Mbarki, R., Ben Miloud, N., Selmi, S., Dhib, S., \& Sadok, S. (2009). Effect of vacuum packaging and low-dose irradiation on the microbial, chemical and sensory characteristics of chub mackerel (Scomber japonicus). Food Microbiology, 26, 821-826. http://dx.doi.org/10.1016/j.fm.2009.05.008

Nazemroaya, S., Sahari, M. A., \& Rezaei, M. (2011). Identification of fatty acid in mackerel (Scomberomorus commersoni) and shark (Carcharhinus dussumieri) fillets and their changes during six month of frozen storage at $-18^{\circ} \mathrm{C}$. Journal of Agricultural, Science and Technology, 13(4), 553-566.

Oduro, F. A., Choi, N., \& Ryu, H. (2011). Effects of cooking conditions on the protein quality of chub mackerel Scomber japonicus. Fisheries and Aquatic Sciences, 14(4), 257-265. http://dx.doi.org/10.5657/FAS.2011.0257

Özogul, Y., Özogul, F., \& Alagoz, S. (2007). Fatty acid profiles and fat contents of commercially important seawater and freshwater fish species of Turkey: A comparative study. Food Chemistry, 103(1), $217-223$. http://dx.doi.org/10.1016/j.foodchem.2006.08.009 
Özyurt, G., Polat, A., \& Tokur, B. (2007). Chemical and sensory changes in frozen $\left(-18{ }^{\circ} \mathrm{C}\right)$ wild sea bass (Dicentrarchus labrax) captured at different fishing seasons. International Journal of Food Science and Technology, 42, 887-893. http://dx.doi.org/10.1111/j.1365-2621.2006.01302.x

Petillo, D., Hultin, H. O., Krzynowek, J., \& Autio, W. R. (1998). Kinetics of antioxidant loss in mackerel light and dark muscle. Journal of agricultural and food chemistry, 46(10). http://dx.doi.org/4128-4137.10.1021/jf980364z

Sahena, F., Zaidul, I. S. M., Jinap, S., Saari, N., Jahurul, H. A., Abbas, K. A., \& Norulaini, N. A. (2009). PUFAs in fish: extraction, fractionation, importance in health. Comprehensive Reviews in Food Science and Food Safety, 8, 59-74. http://dx.doi.org/10.1111/j.1541-4337.2009.00069.x

Sanchez Pascua, G. L., Casales, M. R., \& Yeannes, M. I. (2001). Influence of water and glycerol contents on the aw of fish pastes. Journal of Aquatic Food Product Technology, 1(10), 89-91. http://dx.doi.org/10.1300/J030v10n01_08

Shahidi, F., \& Zhong, Y. (2005). Lipid Oxidation: Measurement Methods, In F. Shahidi (Edit.), Bailey's Industrial Oil \& Fat Products, Wiley-Interscience, (p. 357). A John Wiley \& Sons, New Jersey. http://dx.doi.org/10.1002/047167849X.bio050

Shakila, R. J., Vijayalakshmi, K., \& Jeyasekaran, G. (2003). Changes in histamine and volatile amines in six commercially important species of fish of the Thoothukkudi coast of Tamil Nadu, India stored at ambient temperature. Food Chemistry, 82, 347-352. http://dx.doi.org/10.1016/S0308-8146(02)00552-6

Sohn, J. -H., Taki, Y., Ushio, H., Kohata, T., Shioya, I., \& Ohshima, T. (2005). Lipid oxidations in ordinary and dark muscles of fish: influences on rancid off-odor. Development and color darkening of yellowtail flesh during ice storage. Journal of Food Science, 70(7), s490-s496. http://dx.doi.org/10.1111/j.1365-2621.2005.tb11497.x

Stodolnik, L., Stawicka, A., Szczepanik, G., \& Aubourg, S. P. (2005). Rancidity inhibition study in frozen whole mackerel (Scomber scombrus) following flaxseed (Linum usitatissimum) extract treatment. Grasas y Aceites, 56(3), 198-204. http://dx.doi.org/10.3989/gya.2005

Stolyhwo, A., Kolodziejska, I., \& Sikorski, Z. E. (2006). Long chain polyunsaturated fatty acids in smoked Atlantic mackerel and Baltic sprats. Food Chemistry, 94(4), 589-595. http://dx.doi.org/10.1016/j.foodchem.2004.11.050

Tironi, V. A., Tomá s, M. C., \& Añón, M. C. (2007). Lipid and protein deterioration during the chilled storage of sea salmon (Pseudopercis semifasciata). Journal of the Science of Food and Agriculture, 87(12), 2239-2246. http://dx.doi.org/10.1002/jsfa.2949

Tironi, V. A., Tomás, M. C., \& Añón, M. C. (2010). Quality loss during the frozen storage of sea salmon (Pseudopercis semifasciata). Effect of rosemary (Rosmarinus officinalis L.) extract. LWT-Food Science and Technology, 43(2), 263-272. http://dx.doi.org/10.1016/j.lwt.2009.07.007

Tongnuanchan, P., Benjakul, S., Prodpran, T., \& Songtipya, P. (2011). Characteristics of film based on protein isolate from red tilapia muscle with negligible yellow discoloration. International Journal of Biological Macromolecules, 48(5), 758-767. http://dx.doi.org/10.1016/j.ijbiomac.2011.02.017

Undeland, I., Ekstrand, B., \& Lingnert, H. (1998). Lipid oxidation in herring (Clupea harengus) light muscle, dark muscle, and skin, stored separately or as intact fillets. Journal of the American Oil Chemists' Society, 75(5), 581-590. http://dx.doi.org/10.1007/s11746-998-0069-9

Wetterskog, D., \& Undeland, I. (2004). Loss of redness ( $\left.a^{*}\right)$ as a tool to follow hemoglobin-mediated lipid oxidation in washed cod mince. Journal of agricultural and food chemistry, 52(24), 7214-7221. http://dx.doi.org/10.1021/jf0307907

\section{Copyrights}

Copyright for this article is retained by the author(s), with first publication rights granted to the journal.

This is an open-access article distributed under the terms and conditions of the Creative Commons Attribution license (http://creativecommons.org/licenses/by/3.0/). 